\title{
Landscapes of Inequality? A Critique of Monumental Hierarchy in the Mongolian Bronze Age
}

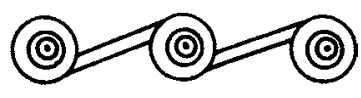

\author{
JOSHUA WRIGHT
}

\section{INTRODUCTION}

The EMERGENCE OF COMPLEX POLITIES and adoption and spread of nomadic pastoralism on the Inner Asian Steppe are important narratives in the archaeology of Inner Asia (Anthony 2007; Chard 1974; Honeychurch and Amartuvshin 2006; Renfrew 1987; Sherratt 2003; Sinor 1969). Central to these narratives is the question of how stable societies reproduced in an unstable mobile social landscape. Analyzing the dominant archaeological material of the Eurasian Steppe, that is, the stone monuments that are found in myriad forms and scales throughout the region, is fundamental to addressing this question.

Allard and Erdenebaatar (2005), analyzing the wide range of sizes of monuments of the Khanny valley landscape, argue that massive monuments were built as emerging Bronze Age elites competed to establish themselves in an unstable social landscape. Looking at the same landscape, Houle (2009:367) similarly proposes that large monuments were productions of a chiefly elite and therefore manifestations of increasingly integrated social hierarchies. In this article, I argue that the scale of a monument was not necessarily a manifestation of the power of an emerging elite, but instead part of a broad strategy enacted by early pastoralists who sought to build a stable social landscape.

Highlighting a common experience of archaeologists studying the Bronze Age (c. 3800-2600 B.P.) in Mongolia, Houle writes (2009:372) that much of what we understand to be evidence of hierarchy is missing from the archaeological record. Despite the existence of monumental landscape forms (Fitzhugh 2009; Frohlich et al. 2009) and massive monuments such as Urt Bulagyn (Allard and Erdenebaatar 2005; Fig. 1) and Sandaohaizi (Fig. 2), so much is missing from the Bronze Age record that strong claims of hierarchy seem to be wishful thinking based on hindsight developed from the clear monumental hierarchies of the Iron Age (c. 2800-2300 B.P.) and later 


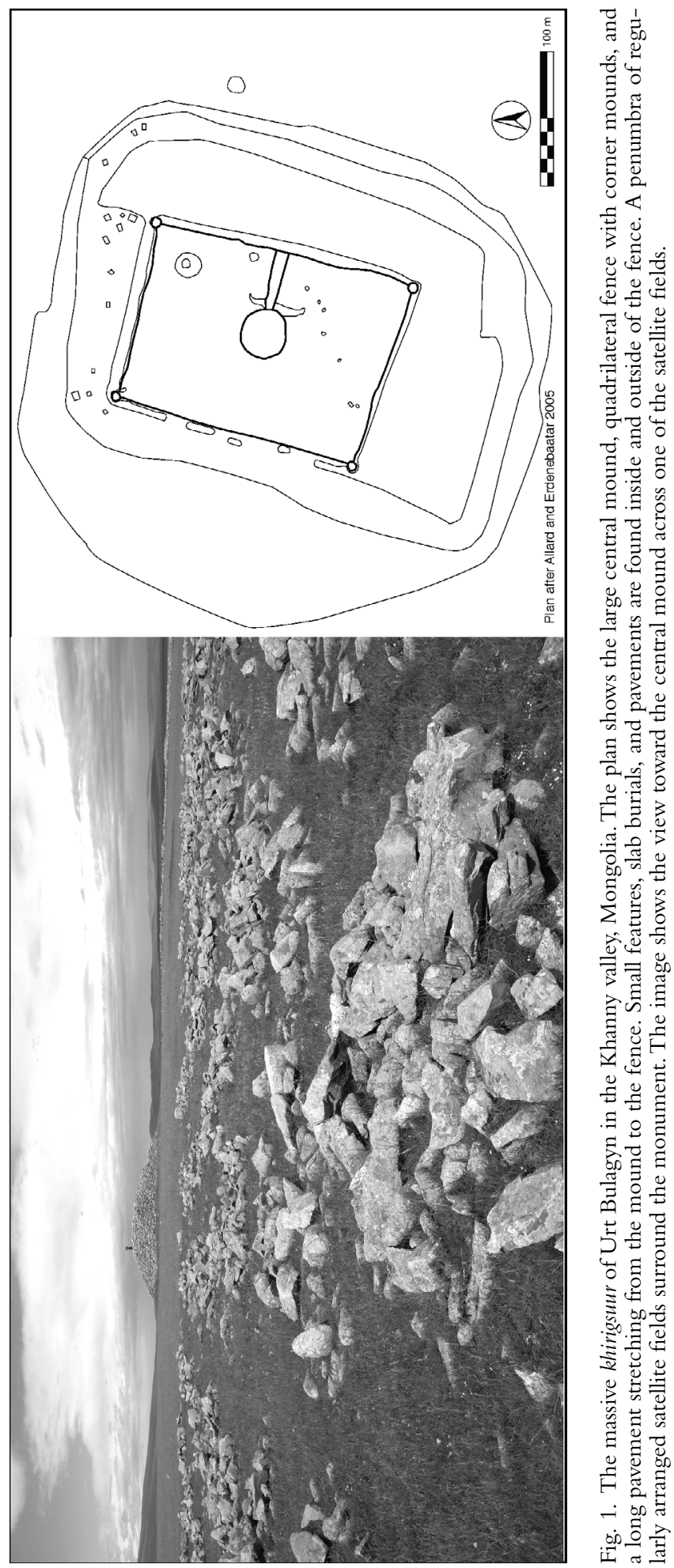




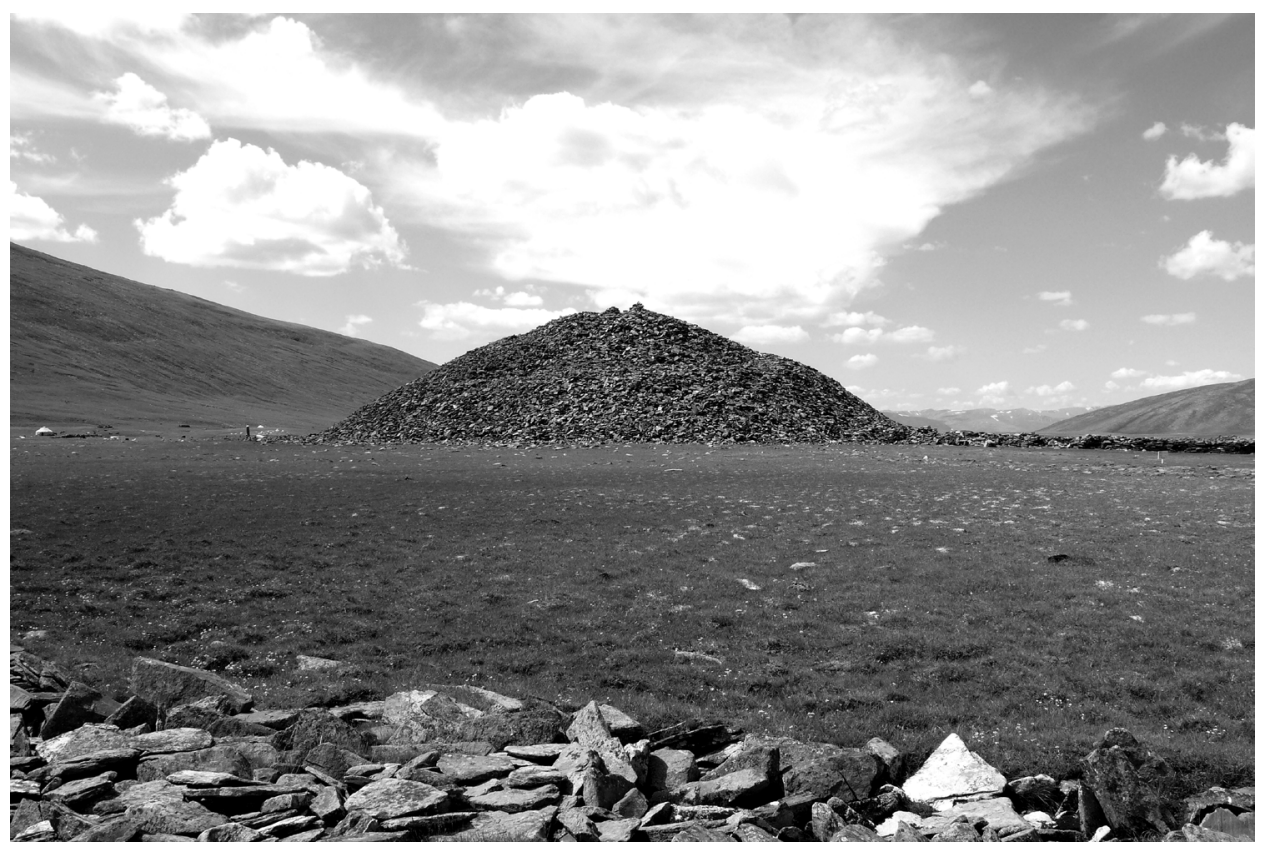

Fig. 2. The massive khirigsuur at Sandaohaizi. Qinghe County, Xinjiang, China. The mound is $55 \mathrm{~m}$ across at the base; the first of two circular fences (foreground) is $70 \mathrm{~m}$ from the base of the mound.

(e.g., Brosseder and Miller 2011; Chang et al. 2003; Cugunov et al. 2003; Hanks 2002). ${ }^{1}$

With that in mind, I offer an exegesis on the application of monumental hierarchy to the Bronze Age of Mongolia and propose an alternative interpretation. The nature of early pastoralism and the context of huge monuments among a wide range of similar structures in central and western Mongolia makes room for a model in which the construction and use of monuments was a more egalitarian experience during the Bronze Age than in succeeding periods. That Bronze Age pastoral nomadic society was acephalous or segmentary and in need of stabilizing forces is not a unique idea. However, I separate that condition from the emergence of a Bronze Age elite by arguing that the main archaeological remains that usually imply social hierarchy (i.e., monuments) were primarily spaces for transegalitarian or heterarchical interactions.

This article is grounded in a contextual and experiential analysis of monuments and monumental landscapes (Bradley 1993; Brück 2005; Parker-Pearson and Ramilisonina 1998; Richards 1993, 2005). Though Mongolia lacks the extensive archaeological dataset that underlies the study of monuments in northern Europe, there is growing recognition that monuments in Mongolia are more than simple burial markers, so their analysis would be enlivened by a more interpretative approach (Houle 2009; Wright 2007, 2012). I am also working within a contextual view of the archaeology of pastoral nomadism in Mongolia (Honeychurch and Amartuvshin 2006; JacobsonTepfer et al. 2010) and Central Asia (Anthony and Brown 2007; Frachetti 2008; Krader 1957; Nomokonova et al. 2010; Popova 2009) in which human ecology and the interrelationships of spatially associated classes of different archaeological data are central to interpretations of ancient society. Finally, studies of the active materializa- 
tion of ideology and the effect of material culture on ideology (DeMarrias et al. 1996; Jackson and Wright forthcoming; Robb 2005), the anthropology of collective action (Edmonds 1999; Ostrom 2000; Roscoe 2000), and the examination and critique of hierarchy in the archaeological record (Crumley 1987; Lightfoot 1989; Price 1981) all underlie my approach.

My critique of hierarchy draws on models of heterarchy in which forms of governance and social action are seen to function through the dynamics of units that are of generally equal rank in a society (Crumley 1987, 1995; Kradin 2011; Levy 1999). Power in a heterarchical system is responsive to circumstances, which means that individual agents can have multiple status relationships within larger society. Such a system is adaptable and responsive to change but also politically unstable as power relationships shift and a new social landscape must be navigated. Location, movement, and political relations are tied together within the unstable social landscapes of mobile populations. In terms of patterns of organization of space (i.e., frequency, routes, and regularity of movement), stable landscapes reflect relatively stable and horizontally integrated political dynamics.

The Bronze Age cultural landscape included a wide range of actors, including pastoral agriculturalists, hunter-gatherers, migratory populations, and food producers, some of whom must have been only a few generations removed from being gatherers and hunters. These people brought forth a new social order within a common milieu of population mobility. Broadly speaking, the climate and environment of the steppe and forested steppe of Inner Asia favors subsistence adaptations that make central use of population mobility (Barfield 1993; Dyson-Hudson and Dyson-Hudson 1980). Studies of graves demonstrate that Bronze Age nomadic pastoralists first appeared in the Western Altai at the extreme edge of the Central Asian Steppe around 4800 B.P. (Görsdorf et al. 2001; Jia et al. 2009; Kovalev and Erdenebaatar 2009), in the Lake Baikal Region (Nomokonova et al. 2010; Weber 1995) and Northern Mongolia (Turbat et al. 2003; Wright et al. forthcoming) by 3400 B.P., and the eastern edges of the Inner Asian Steppe and the Amur drainage by 3000 B.P. (Shelach 2009). The entire region was characterized by low population density, with few long-term settlements occupied by agriculturalists or foragers. This period also saw the florescence of monument building in Inner Asia. A wide array of monumental forms and constellations of monuments have been found across the region, exhibiting widespread patterns of common elements and forms.

By what means did Bronze and Early Iron communities in Inner Asia seek to ensure their cohesion as they adopted and refined the practice of nomadic pastoralism in an unstable social environment? The basic contention of this article is that, rather than establishing and maintaining hierarchy, constructing monuments was primarily a way of building and maintaining social solidarity in an environment where low density, nomadic populations were the norm and bounded territorial rulership was uncommon.

I start by critiquing the assumption that a monumental landscape demonstrates a concept of social order that must be dominated by hierarchy and that hierarchy is therefore visible in the qualities of monumental structures. This model does pertain to the Central Asian Steppe, where burial mounds of many scales contain rich burials of paramount individuals and the interments of other associated people (Anthony 2007; Cugunov et al. 2003; Hanks 2002; Konovalov 2008; Miller et al. 2008; Shishlina et al. 2000; Stark et al. 2012; Zadneprovskiy 1994). However, the large monuments and many of the smaller ones from the Mongolian Bronze Age that have been excavated 


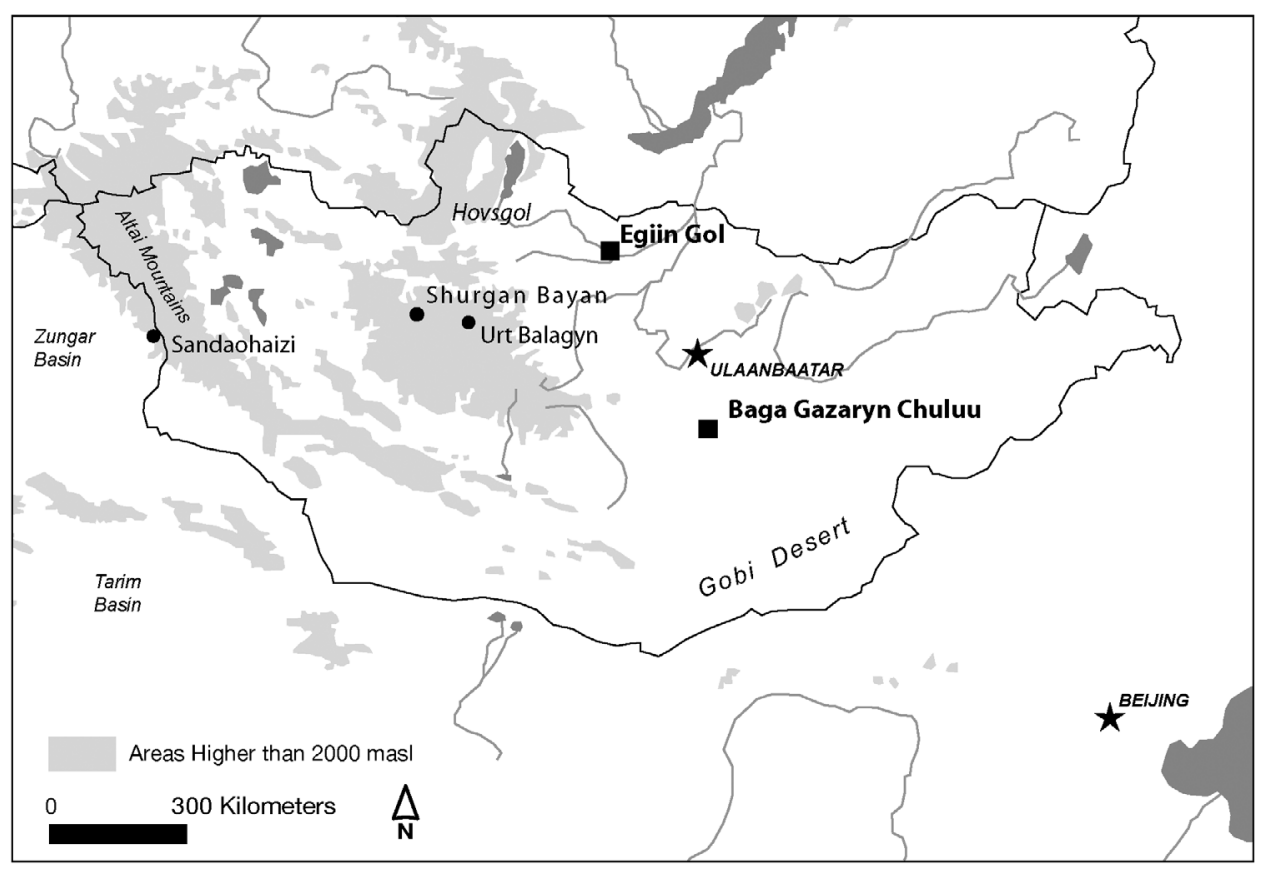

Fig. 3. Mongolia and the sites and regions discussed in the text.

to date have not yielded the rich and varied tombs of those other regions and times (Erdenebaatar 2002; Frohlich et al. 2009; Kovalev and Erdenebaatar 2009; Marcolongo 2005; Tsybiktarov 1995; Turbat et al. 2003).

Data for this article are drawn from the central portion of Eastern Inner Asia, specifically from the lower Egiin Gol valley in Bulgan Aimag, Mongolia (Honeychurch and Amartuvshin 2006; Honeychurch et al. 2009; Wright et al. forthcoming) and Baga Gazaryn Chuluu in Dorngov Aimag, Mongolia (Wright et al. 2007). Other archaeological evidence comes from the Hovsgol region (Frohlich et al. 2009), the Middle Ider valley and Khanny valley in the Khangai Mountains (Houle 2009; Houle and Erdenebaatar 2009), the Southern Altai of Mongolia, South Siberia (Tsybiktarov 1995), and Qinghe County, Xinjiang, China (Fig. 3).

\section{LANDSCAPES OF INEQUALITY}

Landscapes of inequality are landscapes in which the dominant experience of the population in a landscape is distinctly related to a perceived hierarchy, and an observer of the built environment cannot help but be aware of where they stand in that hierarchy. For our purposes, landscapes of elite tomb mounds (Chochorowski and Skoryi 1997; Cugunov et al. 2003) are the obvious example, but this theme also encompasses spaces and landscapes shaped by the status contests of the elite (Johnson 2002; Leone and Shackle 1990), or the political landscapes of early complex societies (Lamberg-Karlovsky 1994; Smith 2003; Wenke 1991). When this characterization is applied to the monumental landscape of the Mongolian Bronze and Early Iron Age, most monuments are viewed as tombs or mortuary monuments for individuals, and 
those individuals are assumed to be the members of an elite class who have the ability to command labor. The more powerful a ruler, the more labor they commanded and the larger monument they might have had built through that secured labor.

Smaller monuments that cluster around these large elite monuments gained status through affiliation, creating an image of a living hierarchical society set in stone. Contemporary and later visitors to these monumental arrays would have been expected to understand this basic equation and respect the power of the chief who commanded the monument to be built, and have been able to visualize their own place in that society. This scheme depends on the association of monuments with individuals, the possibility of the hierarchical mobilization of labor at the command of an elite, and a clear hierarchy of scale or form of monuments. None of these factors are clearly evidenced in the Mongolian archaeological record. Focusing particularly on scale and form, I will question the idea that the monumental landscape of Bronze and Early Iron Age Mongolia is a landscape of inequality, and suggest instead that several aspects of monumental scale and complexity that are central to this interpretation can be explained as mechanisms for maintaining heterarchical political cohesion in a mobile pastoralist society.

\section{THE ORGANIZATIONAL CHALLENGES OF EARLY PASTORAL NOMADISM}

The human ecology of Inner Asian pastoral nomads is a complex and organized system that depends on detailed knowledge of domestic animals and the natural world, wide-ranging and flexible social networks, and sustainable and repeatable use of resources to create a robust subsistence system. Though there are always variations, the archetypical nomadic yearly round of the Inner Asian pastoralist is a winter spent at a sheltered and frequently isolated campsite working to sustain their herds through the hardest time of year. In spring there is a movement to the closest and most accessible fresh grass to restore their animals. Late spring is typically the time when new animals are born. Summer is a time of gathering onto open flat ground with water, accessible valleys, rich grass, and open breezy spaces that are comfortable for humans and animals. The coming of fall sees a movement back into sheltered valleys with their summer growth available to strengthen the herds for the coming winter. The length and frequency of movements is highly variable depending on the social landscape and environmental situation (Barfield 1993; Ekvall 1968; Fernandez-Gimenez 2000; Mearns 1993; Simukov 2007 [1934]; Vainshtein 1980). When crises arise, the pastoralists must make unscheduled moves, adapt to protect their herds, and fall back on others to share their grazing and shelter resources (Bollig and Göbel 1997; Murphy in press; Roe et al. 1998; Xie and Li 2008).

There are differences between mid-to-late first millennium B.c.E. Iron Age nomadic pastoralists and the Early Bronze and Iron Age pastoralists who preceded them in the region. The historically known late first millennium B.C.E. politically stable Xiongnu confederation (Barfield 1981; Di Cosmo 2002; Lewis 1990) and their immediate Iron Age antecedent groups provide some evidence for long- and short-range networks demonstrated by shared ceramic styles and the movement of raw materials (Hall et al. 1999; Hall and Minyaev 2002; Honeychurch and Amartuvshin 2006), as well as using winter penning of livestock in a way similar to modern Inner Asian pastoralists (Makarewicz 2011, 2014). These practices could be indicative of the sort of 
economic safety nets that we see used in recent times in response to political, seasonal, and environmental crises.

Bronze and Early Iron Age pastoral nomads on the other hand appear less organized than their late first millennium B.C.E. successors, without the same level of practical networks and connections that make contemporary nomadic pastoralism so robust. Material culture from this earlier period shows that though there are syncretic elements and contacts across the cultural landscapes of these early nomadic pastoralists (Anthony 2007; Erdenebaatar 2002; Frachetti 2008; Gorynova 1983; Houle 2009), these may not represent the range or depth of assistive networks that are so important to the economic survival and long-range political organization of pastoral nomads. Living as part of less robust networks, the people of the Bronze and Early Iron Age may not have been as able to adapt and recover from crises and reverses as well as their successors, and thus would have great incentive to create new and stable systems of economic security and political organization to increase their chance of survival as mobile pastoralists.

What is at stake in a diffuse social landscape such as that of early pastoral nomads? Ethnohistorical sources reaching back into the terminal Iron Age (c. 2100 B.P.) discuss the fluidity of political allegiance and the permeability of political space in the social landscape of Inner Asian mobile pastoralists, where diffuse populations are frequently spread out over a large area and individually vulnerable to violence or persuasion to shift their political allegiance (Cleaves 1982; Sinor 1990; Tekin 1969; Watson 1961). The same issues would have been at play in the less organized landscape of early pastoral nomads. The great dangers that a mobile community must face are the fissioning of the social units on which collaborative networks of support depend and the loss of access to resources for livestock-graze, water, and winter shelter-without which their animals will suffer and die. Leaders and communities must assure that they can deliver access to networks and resources to their constituents and that what is available is not over-taxed.

Unstable organizations would have caused the political situation to become fluid and anarchic and communities and networks to disintegrate as individuals and small groups left one social or political network to join another. The loss of members diminishes the original community's chances of success as pastoralists. Thus, the maintenance of networks of mutual support, local social cohesion, and statements of access control in nodal regions of the pastoralist economic landscape are critical to nomadic pastoralist communities (see also Houle 2009). This scenario is not one that requires chiefs; much of the decision making could be done by individual herders or ad hoc collectives (Mearns 1996; Murphy in press). Without the regular recognition of an office of rulership, another framework for a stable social and economic landscape was needed.

\section{KHIRIGSUURS}

The evocative, memorial, and symbolic qualities of monuments enable communities and leaders who are not operating within rigidly defined political and social spaces to make claims about their place in the political and social world, their occasional presence in a locale, and their scale of group organization. Monuments are also able to draw people into a community of common experience whether or not all members 
of that community are physically present at the monumental site (e.g., Basso 1996; Hegmon 1989). Monuments and monumental landscapes are concepts of order that provide an external reminder of past activities and individuals. Their spatial organization and structure, arrangements into groups, inter-visibility, requirements for labor organization, positioning in relation to productive territory, and so on make them defining features of the local landscape. The structures provide stages for human activity and they are themselves staged against natural geological and topographic backdrops. Their durability over time and frequency of occurrence in the landscape mean that any individual's experience of space and place would be structured by their experience of the monuments; the monuments in turn provide a comprehensible way for people to express concepts of order to one another. Those who were knowledgeable about the vocabulary of the monuments can communicate complex information, creating the potential for contributions to the monumental dialogue (Fleming 1973; Glassie 1975; Lewis et al. 1998; Wright 2007).

The focus of this discussion will be a particular type of monumental structure that is found throughout central and western Mongolia, Tuva, the Sayano-Altai region, the Altai Mountains, and northwestern Xinjiang. These are a form of monument that creates enclosed areas commonly known as khirigsuurs (Fig. 4). They are so common and visible in some areas that it can be argued that they were the defining features of the human landscapes of prehistoric Inner Asia. Khirigsuurs occur in large quantities wherever they are found. They almost always occur in associated groups and complexes of monuments containing cascades of different monumental forms and complementary arrangements of smaller structures with larger and more elaborate ones. In areas with high monumental density there are often hundreds of examples in single valleys or around a particular mountain (Frohlich et al. 2009:101, figure 3; Magail et al. 2009; Wright et al. 2007; Wright et al. forthcoming). It can be deduced that there are tens of thousands of khirigsuurs throughout their distribution area. This vast number, along with the common vocabulary of monumental components amongst khirigsuurs, suggests that knowledge about the use and construction of monuments was common and acquired by individuals through hands-on experience (Ingold 2000). Their shared ties with the phenomenon of monumentality would have provided people with a sense of local social cohesion.

Khirigsuurs are made up of an array of stone mounds and alignments. The basic form is a central mound of stones surrounded by a ground-level stone fence line in a round or quadrilateral shape. Quadrilateral fences are often aligned in reference to cardinal directions. A wide array of additional features can be found as components of khirigsuurs. Smaller mounds of stone built into the fences or arrayed outside the fence are common; elaborate arcs and lines of ground-level stone fence exterior spaces in patterns of circles, avenues, and rays; and quadrilateral areas of flat-lying stone pavement are found both outside and inside fence lines. Some monuments incorporate the different colors of component stones as part of the design, although this is not frequent. Other khirigsuurs include burial monuments or carved standing stones as part of their fabric (Jacobson-Tepfer et al. 2010; Khudiakov 1987; Tsybiktarov 1995). This wide array of optional components in khirigsuur structures results in tremendous variability, but the fact that all the final forms spread over the large region of Mongolia and south Siberia are made up of the same component parts suggests a common monumental vocabulary existed amongst the peoples of Bronze and Iron Age Inner Asia (Wright 2007). 


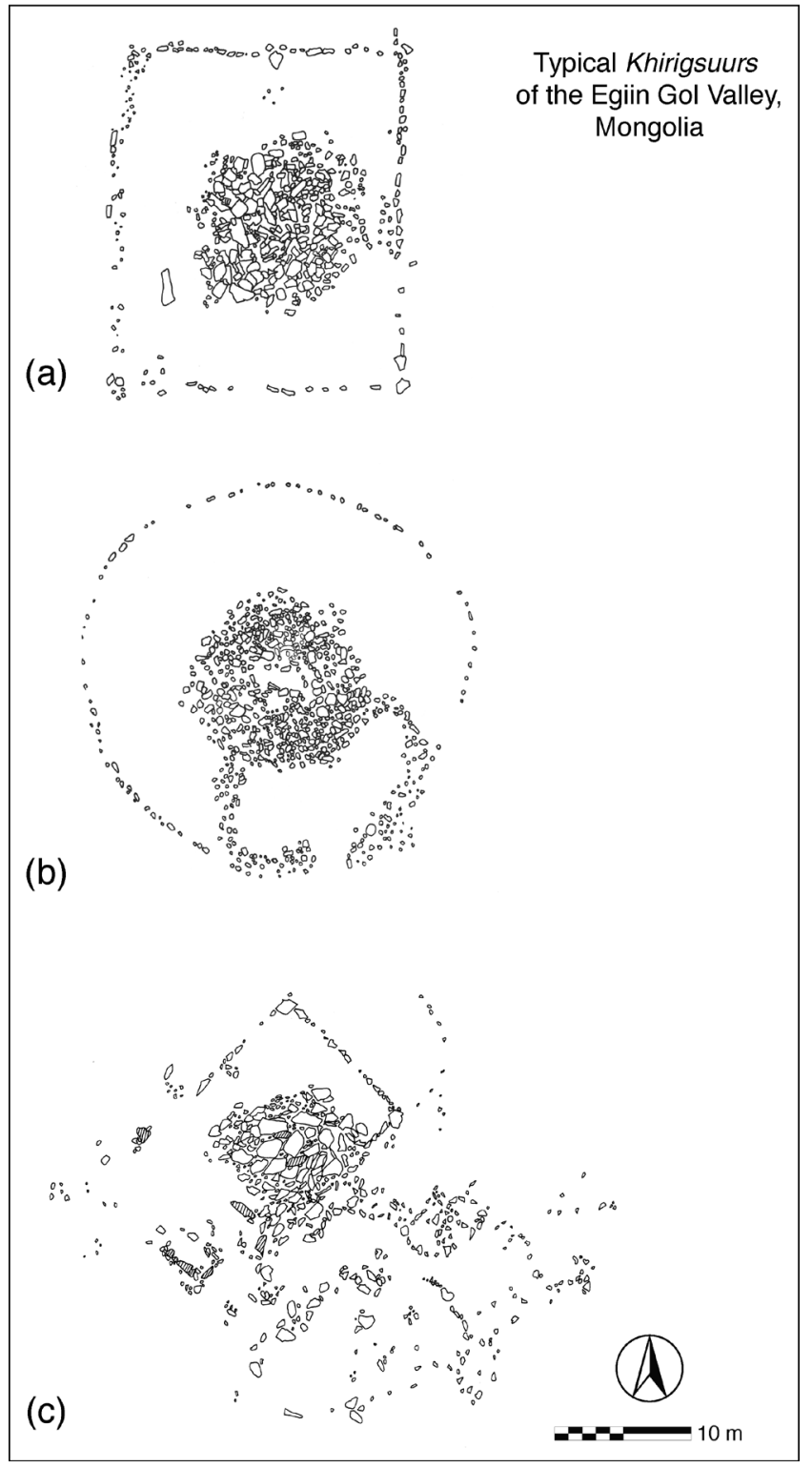

Fig. 4. A range of khirigsuur plans from the Egiin Gol valley showing typical forms and variations. (a) A quadrilateral fenced mound. (b) A circular fenced mound with arms creating a clear orientation and separated space in front of the mound. (c) An off-center mound with a quadrilateral fence pointing to the cardinal directions. A slab burial was incorporated into the northwest part of the monument; an array of satellite features remain to the southeast.

Building on experience in other regions of Eurasia, particularly the Central Asian Steppe, khirigsuurs are frequently categorized as mortuary monuments. Their exterior size is often interpreted as a manifestation of the status of the memorialized individual, similar to the earth, wood, and stone kurgan burial mounds found in the Central Asian Steppe and forested steppe. Khirigsuur mounds do not follow the same pattern as kurgan mounds, however (Fitzhugh 2009; Frohlich et al. 2008, 2009; Houle 2009; Tsybiktarov 1995; Turbat et al. 2003). Kurgan mounds frequently contain burials with different levels of elaboration related to the size of the mound (Cugunov et al. 2003; 
Hanks 2002; Kubarev 1991; Stark et al. 2012). By contrast, the burials found within khirigsuurs are sometimes under the central mounds but other times in attached burial structures that are parts of the ground-level features of the monument. Furthermore, khirigsuur-related burials tend to be without grave goods or large cists and sometimes appear to be incomplete interments (Frohlich et al. 2008, 2009; Littleton et al. 2012; Takahama and Hayashi 2003). Animal remains found within khirigsuur components are also often incomplete (Erdenebaatar 2002; Takahama and Hayashi 2003; Takahama et al. 2004; Turbat et al. 2003). All these factors suggest that complex khirigsuurs were not primarily burial monuments, but may have sometimes required human or animal remains as elements of their constituent parts.

Having questioned the assumption that khirigsuurs (the dominant monumental form of the eastern steppe) were intended to be solely mortuary monuments demonstrating the social position of individuals during the Mongolian Bronze Age, I now turn to a critique of the argument that these monuments were representations of political power and hierarchy. I argue that the scale of a monument did not indicate the social status of an individual. Instead, the form of a monument was a record of a group or community's activities around that monument. Though one does not preclude the other, I suggest that social interactions surrounding these monuments were the most important aspect of the sites.

\section{Monumental Scale}

The scale and quantity of khirigsuur monuments mean that they were not related to rare or unique events or social classes, but were a common aspect of life in the Bronze Age of Inner Asia. Most khirigsuurs are built around central mounds that are less than $10 \mathrm{~m}$ in diameter and stand less than $2 \mathrm{~m}$ high; their associated ground-level features cover 0.2 ha or less (Fig. 4). There are tens of thousands of examples in this size range. A lesser but still substantial number occur in larger sizes with maximum ground-level features extending up to 1 ha (Fig. 5). A small number of monuments are an order of magnitude larger, with central mound diameters in the range of 50-100 m (Figs. 1, 2). In a landscape of inequality, these largest monuments would be expected by archaeologists to be memorials for paramount individuals in a social hierarchy. Their formal similarity to the more traditional smaller khirigsuurs and the parallels that can be drawn about their uses and histories suggest that scale is really a measure of group involvement, not a marker of exceptionally high individual status.

Aside from size, the mega-monuments are otherwise little different from the khirigsuurs typical for the region in which they were built. Unlike the general similarity in form seen among Central Asian kurgan burials, the component types and configurations of khirigsuurs are all almost exactly the same, no matter how large (Fig. 6). The same fence, arms, incorporated burial monuments, and satellite mounds are always in evidence; not all are proportionally larger. These giant khirigsuurs communicate with the same vocabulary of components and spaces as normal-sized examples. They are notable places that could be revisited over time, offering similar spaces and divisions that demonstrate differences within a group.

The khirigsuur is only one type of monument among many that is sometimes enlarged. The super-sizing phenomenon is seen in other monument types in prehistoric Mongolia. In the lower Egiin Gol valley, for example, Middle and Late Bronze Age 


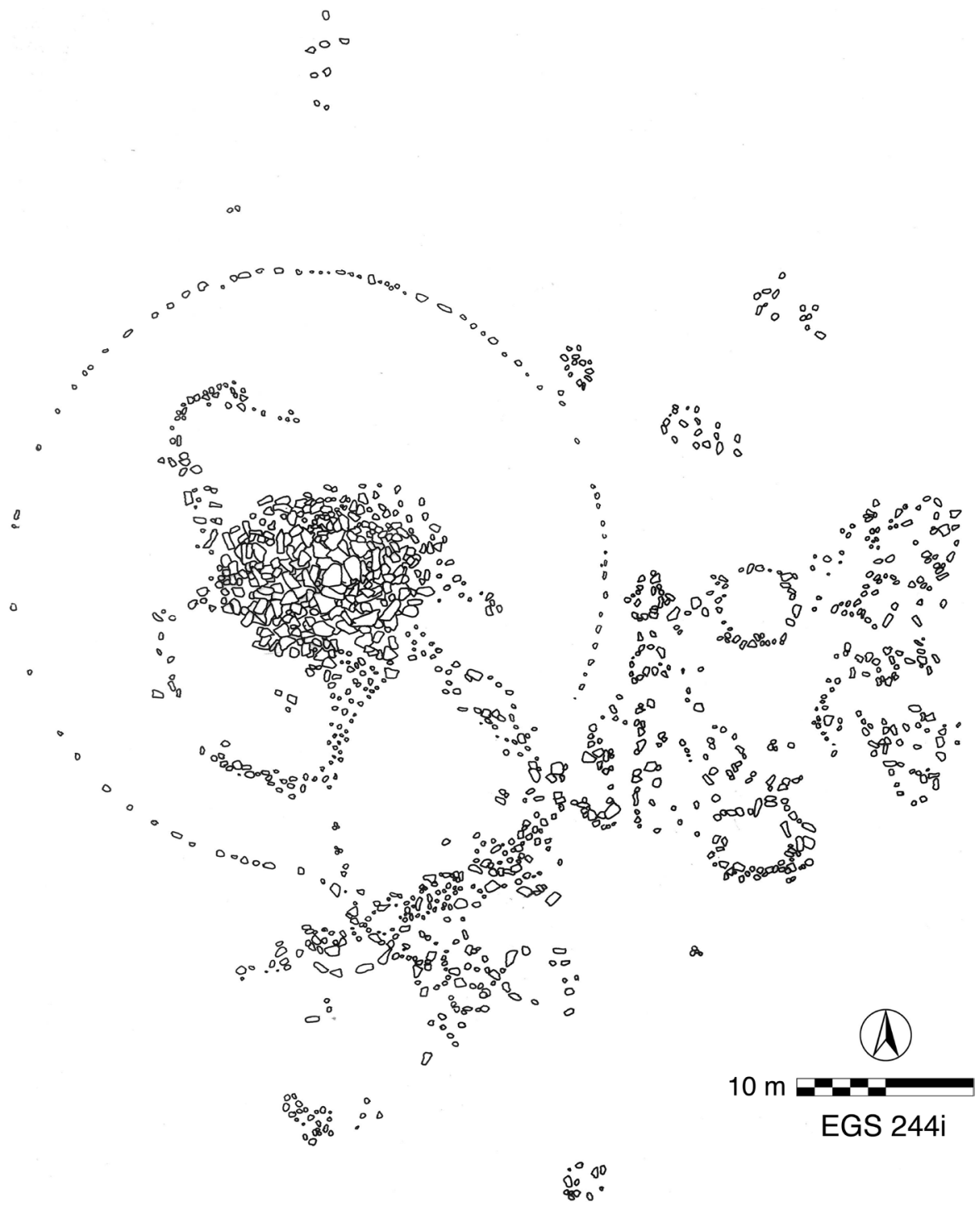

Fig. 5. This plan shows a highly elaborated khirigsuur. Though the central mound is not exceptionally large, the monument has several arms and negative circles laid out on the ground within the fence and a large haphazard array of various satellite features outside of the fence to the southeast.

slab burials range from 2.1 to $10 \mathrm{~m}$ in length $(\mathrm{n}=59)$ and at Baga Gazaryn Chuluu in Dundgovi Aimag, they range from 1.6 to $9.3 \mathrm{~m}(\mathrm{n}=271)$. Early Bronze Age shoorguljin or "figure burial" monuments range from 3.5 to $34.5 \mathrm{~m}$ in length $(\mathrm{n}=82)$, with proportional increases in all other structural elements. These two types of monuments all include burials, but frequent re-entry into the graves to remove metal goods and the limited number of excavations so far conducted means that we do not have even anecdotal information to suggest that larger structures contained more grave goods or faunal remains than average-sized graves. This, combined with close formal similarities, 


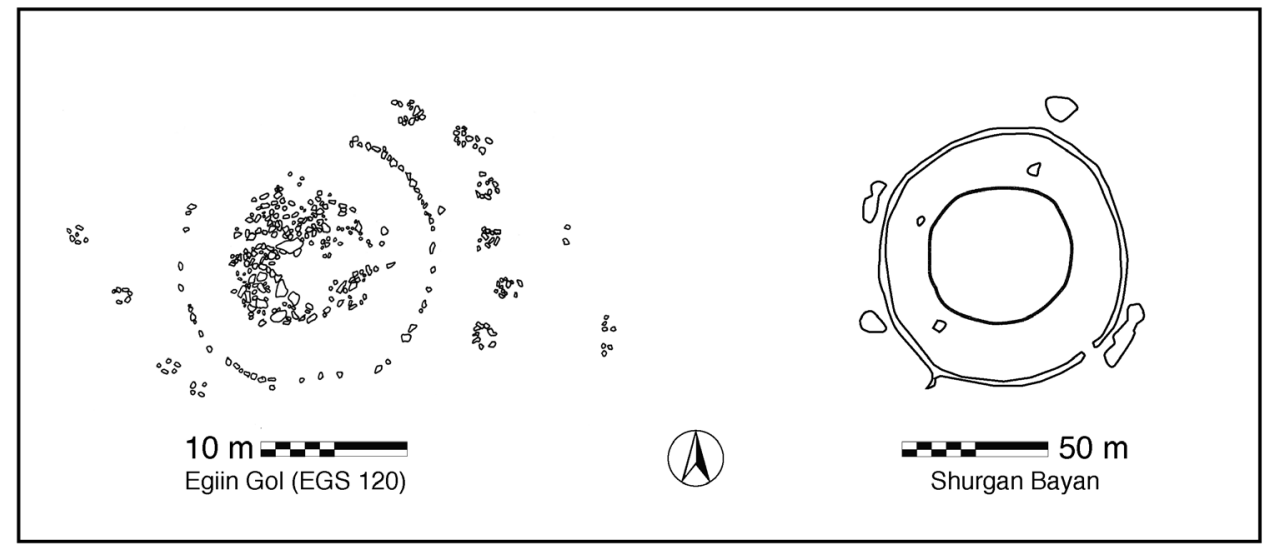

Fig. 6. A comparison of the plans of two similar khirigsuurs. Both have a central mound, a circular fence, and an array of satellite features around the fence. The figure is scaled so the central mounds of the two monuments are of equivalent size, and the actual great size difference is clear from the scale bars. Regardless of the great difference in size, the two monuments have almost identical forms.

leads me to suggest that the scale of a monument is not a key factor in it having enduring meaning to its Bronze and Iron Age visitors; rather its form is.

The importance of form over scale is seen in the typologies various scholars have created to categorize khirigsuurs, none of which treat size as a defining characteristic. Tsybiktarov's (1995) nine types, Frolich et al.'s (2009) three classes, Houle's (2009) two tiers, and Wright's (2007) component-based system are all different typologies of khirigsuur form. Particularly in Frolich et al.'s (2009) work, we can see that size can be a dependent element of form.

If form contains the most informative variation, what is the relationship between elaboration of form and scale? To quantify the scale ranges of different monuments, two measures are used here. The first is the footprint of the central mound, which is a proxy for the amount of labor required to build the monument. No matter how elaborate the ground-level features of a khirigsuur, most of the stone is in the central mound. This figure also provides some measure of the visual impact of the structure because footprint and height are typically related. The second measure is the area enclosed by the ground-level features of the monument. This is also a measure of potential inclusive (i.e., how many people could fit inside the monumental boundary) and exclusive (i.e., how far away observers might stand) distance. Table 1 shows a comparison between the range of khirigsuur sizes from two intensively surveyed regions in Mongolia with huge khirigsuurs in surrounding areas that have not been surveyed. These larger monuments are vastly larger than even the biggest examples in the intensively studied regions of Mongolia, but are otherwise quite similar in form. Anecdotal observations of the areas surrounding these huge monuments reinforce their exceptionality by placing them amid arrays of other ordinary-sized monuments.

The elaboration of khirigsuur form can be measured by observing elaboration in its components (Wright 2007). Khirigsuurs have many associated ground-level features in addition to their fences, including pavement areas outside the fences, circular alignments mirroring their central mounds, entrances or extended arms that penetrate the fence, mounds or standing stones at the corners of their surrounding fences, slab 
Table i. The Range of Khirigsuur Sizes at Different Sites and Areas

\begin{tabular}{lll}
\hline KHIRIGSUURS & MOUND FOOTPRINT $\left(\mathrm{m}^{2}\right)$ & ENCLOSED AREA $\left(\mathrm{m}^{2}\right)$ \\
\hline Average of Egiin Gol khirigsuurs & $81 \pm 45(\mathrm{n}=216)$ & $274 \pm 278(\mathrm{n}=143)$ \\
Largest khirigsuur in Egiin Gol & 380 & 2120 \\
Average of Baga Gazaryn Chuluu & $63 \pm 19(\mathrm{n}=266)$ & $248 \pm 337(\mathrm{n}=167)$ \\
Largest in Baga Gazaryn Chuluu & 314 & 2249 \\
Urt Bulagyn khirigsuur & 530 & $26441^{\mathrm{a}}$ \\
Shurgan Bayan khirigsuur & 1963 & 6082 \\
Sandaohaizi khirigsuur & 4536 & 34636 \\
\hline
\end{tabular}

${ }^{a}$ This value is the enclosed area of the fence, and does not include the extensive satellite fields around the monument.

burials integrated into the khirigsuur, and satellite mounds (Figs. 4, 5). The systematic reproduction of these patterns on different monuments and in different regions suggests that each of these elements of monumental vocabulary had a particular meaning and function to the builders of the monuments. For our purposes here, we will consider them all as equally important. We use these elaborations as a measure of the intensity and complexity of the use of the monuments by adding up the number of types of reoccurring elaborations (i.e., fence, satellites, porch or entryway, pavement areas, arms extending from the main mound, negative circles inside the fence, integrated slab burials) that are present at any particular khirigsuur. The result is that monuments in the two survey areas are equally elaborate on average. There are $2.4 \pm 0.8$ $(n=232)$ types of features per monument in Egiin Gol, while at Baga Gazaryn Chuluu the mean and standard deviation are $2.4 \pm 1.1(\mathrm{n}=329)$. Fences and satellites are by far the most common elaborations. Baga Gazaryn Chuluu has a wider range of variation in the number of types of elaborating features, with the most elaborate structures having six classes of features (compared to five in Egiin Gol monuments).

Design elaboration occurs at all monumental scales, though on the whole the largest monuments are not heavily elaborated (Fig. 7). In Egiin Gol and Baga Gazaryn Chuluu, four or five additional components identify some khirigsuurs as exceptionally elaborate. The three mega-monument examples fall throughout the range in their number of elaborate components, however. Shurgan Bayan has only three different elements, which is not exceptional, while Sandaohaizi's five would be typical of an elaborate khirigsuur. Urt Bulagyn is an exceptionally grand monument, with all seven additional elements of elaboration. The relationship between khirigsuur size and elaboration is shown in Figure 7. The most elaborate monuments occur at all size ranges and are encompassed within the typical size ranges.

We can also see a significant relationship between mound footprint and enclosed area. What this shows us is that there is a design model for the scale of a khirigsuur monument in both these areas; in short, fences relate to mounds. This in itself is not surprising. We see also that though there is a continuum of size, and therefore of labor investment, there are a few exceptionally large monuments in both study areas. In general, these have over $150 \mathrm{~m}^{2}$ mound footprints and $750 \mathrm{~m}^{2}$ of enclosed area. The pattern of relatively few large khirigsuurs is also seen in the Ushkiin Uvir area of Hovsgol Aimag (Frohlich et al. 2009). As noted above, the larger monuments are not necessarily the most intensively elaborated. This supports the argument that there is 

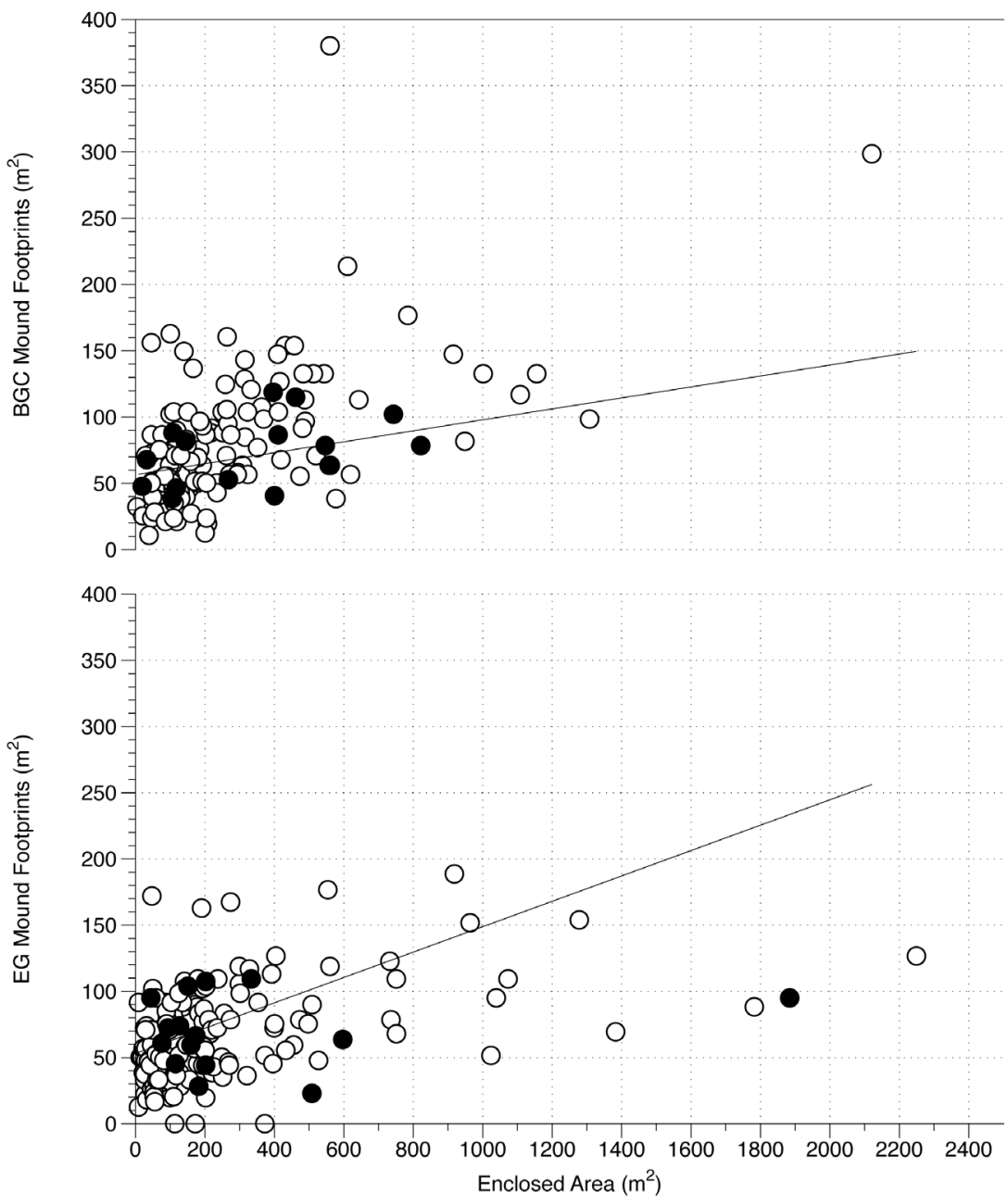

Fig. 7. Scatter plots highlighting the relation of khirigsuur scale to elaboration in the two intensively studied areas. Individual elaborate examples are shown with black dots. This measure of elaboration counts a range of design components, starting with the mound, and including a range of others (Wright 2007). The range of values is between 1 and 6 elements, those with exceptional numbers of elements (4 at EG and 5 at BGC) are highlighted. The correlation of footprint to enclosed at BGC $(r \mid \mathrm{st}=.40$, $\mathrm{n}=165)$ and $\mathrm{EG}(r \mid \mathrm{st}=0.56, \mathrm{n}=140)$ are generally significant, suggesting an overall standard of design for a khirigsuur mound and fence. There is no significant difference between the regression lines (with footprint as independent and enclosed area as dependent variable, $\mathrm{t}=\mid \mathrm{st}-1.0061 \mathrm{df}=300, \mathrm{p}=0.3152$ ), showing that the two study areas' khirigsuurs are of similar scales.

little relationship between the scale of a monument and the intensity and elaboration of its use and that monuments at which the most enduring and complex social relations were enacted were not necessarily the largest ones.

\section{THE ALTERNATIVE TO LANDSCAPES OF INEQUALITY}

The previous range of variation in khirigsuur monuments highlights two axes of variation: size and elaboration. ${ }^{2}$ I have shown that there are monuments of very large size 
and monuments that are intensively elaborated, but in most cases they are not the same structures. These variations make it clear that a hierarchy of scale is not the sole viable measure of the impact any given monumental site had on people in the past. The cultural landscapes of Bronze Age Mongolia cannot be assumed to have followed a scale hierarchy of monuments and this scale should not be used to map onto social or political organization. An alternative interpretation of the khirigsuurs is now called for, one that foregrounds long-term interactions of communities with their monuments (Bradley 1993; Cresswell 2004; Ingold 1993; Robb 2005). Rather than highlighting the status of exceptional individuals, this interpretation focuses on the complex surface forms of monuments to discover information about those engaging with them. I argue that form is built up by design and in repeated visits to the site. Form is then a measure of the importance of a place to an ancient community. The components of monuments and monumental complexes suggest that there was broad access to monumental sites. ${ }^{3}$ Explaining the communicative value of larger monuments brings into focus the workings of ordinary monuments and monumental landscapes.

I have argued elsewhere (Wright 2006, 2007, 2014) that khirigsuurs were primarily monuments that provided stages for the living to demonstrate social distinctions and that they were built to be actively used and repeatedly visited and modified. In brief, the great variation in the external form of khirigsuurs constituted a visible monumental vocabulary accessible to and readable by builders, regular users, and visitors to the sites. The designs of ground-level features of khirigsuurs divided space and provided consensual barriers to movement and association among people moving around the monuments. Among the ground-level features around khirigsuurs are elements and portions of the monuments that could have been foci for the memory of particular events separate from the initial construction of the monument and, along with different spaces, components of multi-stage performances and rituals. Though the monuments were certainly mechanisms for demonstrating and maintaining social difference, they also brought people together as participants and audience. This, combined with the lack of individualizing burials at most khirigsuurs, suggests that they were living monuments that promoted heterarchical, participatory, and event-centered interactions.

There is little direct archaeological evidence for activities around khirigsuur or related to their construction. Human interments, when they are present, are simple and placed into the central mounds unless they are included in another form of monument built into the khirigsuur (Frohlich et al. 2009; Littleton et al. 2012; Tsybiktarov 1995). The one past activity that is widely evidenced is the burial of horses' heads and other fauna in satellite features of the monument. Almost every type of Bronze Age monument in Inner Asia requires fauna to be consumed as part of its construction and use. Khirigsuurs are no different; khirigsuurs of every size can be found with associated faunal remains deposited in very particular ways in their ground-level features. In the vast majority of examples, the construction of the monument required less than 10 horses to be sacrificed during their active periods of use. Horse head mounds use a standardized construction shared with other types of faunal sacrifice: a ring of stones on the ground surface, or set slightly into it, containing a regularly oriented head and partial neck of a horse piled over with a small mound of stones and soil (Allard and Erdenebaatar 2005; Erdenebaatar 2002; Fitzhugh 2009). This standardized form across monument types suggests that horse head mounds are a form of interaction with monumental complexes that had meaning both individually, as each was made, and interchangeably, as a common element of many monuments and monument forms. In 
the regions studied here and in almost all cases these satellite mounds are arranged haphazardly in clusters of mounds gathered to one side of a khirigsuur fence (Fig. 6). These mounds are frequently different sizes, and in denser examples abut and overlap one another. This demonstrates their role in individual events rather than as part of planned complete projects.

There are examples of more regular patterns that suggest planning, however. In these cases, mounds are consistently scaled and placed either in symmetric rings or blocks or more usually in distinctive asymmetric arrays around the fence of the khirigsuur (Fig. 1). These patterns are most common around larger mounds, but some smaller arrays also display them. Massive planned arrays, such as those at the huge monument of Urt Bulagyn in the Khanny valley (Allard and Erdenebaatar 2005; Houle and Erdenebaatar 2009), demonstrate elaborate planning of horse sacrifices as well as monuments as a whole, but the presence of planned arrays at smaller monuments and systematic, appropriately scaled, relatively haphazard arrays of horse head mounds at other larger khirigsuurs demonstrate that there is not a distinct pattern for massive sacrifices at larger monuments.

Faunal remains in satellites most frequently provide directly dated contexts around khirigsuur monuments. The large planned arrays have yielded closely grouped dates, supporting the argument that they were produced in short periods (Allard and Erdenebaatar 2005; Fitzhugh and Bayarsaikhan 2008). However, remains from haphazard arrays of satellite circles or other ground-level features provide a range of dates, sometimes differing by centuries or more, suggesting that these features were added to the monuments after they were initially built and that the addition of such satellites continued for many generations (Fitzhugh and Bayarsaikhan 2008: 1, table 1; Turbat et al. 2003; Wright 2014; Wright et al. forthcoming). Contributing evidence for ongoing modifications includes features such as outsized fences and dense interlinked groundlevel features (Figs. 4c, 6). These additions and modifications of the monuments and building up of the sites suggest repeated events. The modification process is magnified in the construction of monumental complexes and addition of multiple types and examples of different monuments to the same locale (Jacobson-Tepfer et al. 2010; Wright et al. forthcoming).

The visual impact of the khirigsuur monuments is the way in which the monuments affected most people around them most of the time (Llobera 2007). Here we set aside the issues of what events took place at the monuments and at what distance activities around the monuments were visible or audible to concentrate on the range of visual effect of any monument, measured as the distance at which a monument can be seen in any detail. Topographic variability and monument size are related for all the "supersized" monument types, with the largest monuments built in the most visible places such as horizon-breaking hills and ridges, wide open flat valley confluences or plains, and on slopes with a long viewshed. Giant khirigsuurs sometimes stand alone at the center of a plain or confluence of valleys, but are just as frequently found in arrays of giants, where massive khirigsuurs are spread out along a long drainage or stand the mouths of neighboring tributary valleys. These are the sorts of locales that are favored by ethnohistoric pastoral nomads as summer agglomeration sites and important economic and social spaces.

The monuments orient and communicate to every person within a geographical space. The practical distance from which a monument is visible is affected by many factors such as height and topographic position. Ordinary-sized khirigsuurs and human 
scale activities around them are visible at distances of one to two kilometers maximum. The size of the individual viewshed effectively partitions a large valley or basin into a series of several areas within which only one ordinary khirigsuur monument might have a visual impact. A very large monument, however, is visible at such long range that it effectively dominates an entire area, communicates with every observer, and ties together the space that contains it.

Because of their common vocabulary at all scales, their contemporary audiences were able to read khirigsuur monuments as having similar functions; they likely understood the basic equation that scale of a monument is a measure of the number of people involved in its construction and use. This message is key to our understanding of huge monuments. Outside of a specific landscape of hierarchy, the motivation for a group to build a large communal structure was to signal their organization and cohesiveness to outsiders and themselves (Kantner and Vaughn 2012; Roscoe 2000; Smith and Bird 2000). Any large group that came together to build one of these khirigsuurs made a clear and lasting demonstration of their organization and investment in the locale. An outsider who arrived to an area filled with large monuments would probably have read the monuments as a message warning them to avoid conflict with the powerful group that built them. However, the people who received the messages of the monuments more than any others were those who were already there and had personal connections to the building of the structures. For them, the message was primarily one of commitment, proof that they worked together and did not fission easily. Wherever they might move in the short term, they remained anchored to the place were their monuments stood. Thus, monuments define regularly used territories rather than the boundaries of restricted locales. This is an important point of spatial order during the Bronze and Early Iron Ages. This message of solidarity and strong collective action was critical during times of unstable social networks and emerging regional political entities. The monuments provided early nomadic pastoralists with a critical advantage for their survival in an economic and social landscape that was not yet fully refashioned into a landscape structured by the practices of nomadic herders. The position of giant monuments at key places in the economic landscape can be interpreted as a way of signaling group size and cohesion whether the region was inhabited or uninhabited at any point in the seasonal nomadic round. In short, huge khirigsuurs were not monuments to inequality and hierarchy, but mechanisms of group cohesion and solidarity.

In emerging Bronze Age hierarchies, which can be seen in the monumental record of burials in the Iron Age, elaborate and large area monument building was a countervailing force to those hierarchies both in internal terms, by demonstrating that a group must gather to build them and express their place as a group as opposed to fissioning into lineages and each building their own smaller monuments, and in external terms, by telling other leaders or groups who would wish to challenge them that there are a lot of people here and they are already well organized and cohesive.

Finally, ordinary khirigsuurs might have fulfilled similar communicative functions as the larger ones. In the preceding text, I speculated on the use of ground-level features as spaces for consensual organization and on the use of khirigsuurs as stages for rituals and places where repeated events were celebrated or marked. Although the startling visual impact of a large monument would seem to overshadow the impact of smaller monuments, being surrounded on every side by monuments in a single space would 
also communicate a message of enduring presence and mark a community's investment in the place.

In the sparse archaeological landscapes of Mongolia, area monuments and monumental landscapes constitute the main archaeological record of the reproduction and transformation of prehistoric society. Though using monuments as tools for the constitution of politics is a widespread strategy across the eastern Steppe that endured over millennia, it is likely that using monuments as community integration and communication strategies, as I have outlined here, was of relatively short duration. The emergence of successful hierarchical political confederations in the region in the Late Bronze Age and Early Iron Age (Bemmann et al. 2009; Chang et al. 2003; Cugunov et al. 2003; Davis-Kimball et al. 1995; Khazanov 1979) probably spelled the end or failure of the central elements of the more heterarchal system. This occurred after a period of centuries of stabilization of Bronze Age nomadic pastoralism. At the frontiers of emerging hierarchy, the monumental spaces discussed here become a series of nested contested spaces (Low and Lawrence-Zúñiga 2003). With little modification required, the structures originally built for community integration become tools for defining and demonstrating hierarchical difference.

This article has argued for the communicative weight and implications of Bronze Age monuments. Foremost is the contention that the monumental landscape of Bronze Age Mongolia was not necessarily a landscape of inequality. Monuments could exist and function as social mechanisms, built for integrating activities over the short and long term, without assuming a chiefly elite must have commanded their construction. Furthermore, if social differentiation is demonstrated by monumental construction, it is clearly not along a linear scale of size alone, but in an intersection of many measures including size, elaboration, buried objects, location, and monumental context. Most of these categories are intimidatingly variable, but it is here that we may see the subtleties of chronology and typology as well as the residues of social practice and the details of the recognition and enactment of difference between groups and individuals during the Mongolian Bronze Age.

\section{ACKNOWLEDGMENTS}

Without my long-term collaborators William Honeychurch and Chunag Amartuvshin none of this work would be possible and to them I owe a great debt. Additionally, James Williams and Wu Guo were instrumental in this fieldwork and Chris Foster contributed to the monument illustrations. This article is partially made up from papers presented at the 75th Meeting of the Society of American Archaeology, in St. Louis, Missouri (2010), and the 3rd University of Chicago Conference on Eurasian Archaeology (2008).

\section{NOTES}

1. The three massive khirigsuurs discussed are easily visible in Google Earth ${ }^{\mathrm{TM}}$. Urt Bulagyn at $48^{\circ} 4^{\prime} 45.01^{\prime \prime} \mathrm{N}, 101^{\circ} 3^{\prime} 31.74^{\prime \prime} \mathrm{E}$, Shurgan Bayan at $48^{\circ} 25^{\prime} 47.84^{\prime \prime} \mathrm{N}, 97^{\circ} 24^{\prime} 23.52^{\prime \prime} \mathrm{E}$, and Sandaohaizi at $46^{\circ} 48^{\prime} 11.41^{\prime \prime} \mathrm{N}, 90^{\circ} 52^{\prime} 24.89^{\prime \prime} \mathrm{E}$.

2. Other features of variation could be added, including whether or not the monuments anchor large complexes of other monuments, or are widely visible, or have many burials in close proximity, but these aspects are beyond the scope of this article.

3. I lean strongly toward the argument that people engaged heterarchically with area monuments such as khrigisuurs and that most are evidence of collective action (Fireman and Gamson 1977; Mearns 1996; Ostrom 2000). However, it remains plausible, following Frolich et al.'s (2009) interpretation for the three types of monuments documented there, that variation could be related to the hierarchy of the 
group members who used the monuments. It cannot be denied that some monuments are simply much larger than others. The proposed rigid typological division suggests a sumptuary tradition in Bronze Age society, an idea that offers interesting avenues for future research.

\section{REFERENCES CITED}

Allard, Francis, and Ditmaajav Erdenebaatar

2005 Khirigsuurs, ritual and mobility in the Bronze Age of Mongolia. Antiquity 79:547-563.

Anthony, David W.

2007 The Horse, the Wheel, and Language: How Bronze-Age Riders from the Eurasian Steppes Shaped the Modern World. Princeton: Princeton University Press.

Anthony, David W., AND Dorcas Brown

2007 The herding-and-gathering economy at Krasnosamarskoe, Russia, and the end of the dependency model of steppe pastoralism, in Social Orders and Social Landscapes: 393-415, ed. L. Popova, C. Hartley, and A. Smith. Newcastle: Cambridge Scholars.

BARFIELD, ThOMAS

1981 The Hsiung-Nu imperial confederacy: Organization and foreign policy. Journal of Asian Studies 41(1): 45-61.

1993 The Nomadic Alternative. Upper Saddle River, NJ: Prentice Hall.

Basso, K. H.

1996 Wisdom sits in places: Notes on a Western Apache landscape, in Senses of Place: 53-90, ed. S. Feld and K. H. Basso. Santa Fe: School of American Research.

Bemmann, J., H. Parzinger, E. Pohl, and D. Tseveendorzh, eds.

2009 Current Archaeological Research in Mongolia. Bonn: Vor- und Frühgeschichtliche Archäologie Rheinische Friedrich-Wilhelms-Universität.

Bollig, Michael, And Barbara GöBel

1997 Risk, uncertainty and pastoralism: An introduction. Nomadic Peoples 1(1):5-21.

BRADLEY, RICHARD

1993 Altering the Earth, The Origins of Monuments in Britain and Continental Europe. Society of the Antiquaries of Scotland Monograph Series, vol. 8. Edinburgh: Society of the Antiquaries of Scotland.

Brosseder, Urusula, and Bryan K. Miller, eds.

2011 Xiongnu Archaeology, Multidisciplinary Perspectives of the First Steppe Empire in Inner Asia. Bonn: Vor- und Frühgeschichtliche Archäologie Rheinische Friedrich-Wilhelms-Universität.

BRÜCK, JOANNA

2005 Experiencing the past? The development of phenomenological archaeology in British Prehistory. Archaeological Dialogues 12(1):45-72.

Chang, Claudia, Norbert Benecke, Fedor P. Grigoriev, Arlene M. Rosen, and Perry A. ToureTELLOTTE

2003 Iron Age society and chronology in south-east Kazakhstan. Antiquity 77:298-312.

Chard, Chester S.

1974 Northeast Asia in Prehistory. Madison: University of Wisconsin Press.

Chochorowski, Jan, and Sergei Skoryi

1997 Prince of the Great Kurgan. Archaeology 50:32-39.

Cleaves, Francis Woodman, ed.

1982 The Secret History of the Mongols. Cambridge, MA: Harvard University Press.

Cresswell, Tim.

2004 Place: A Short Introduction. Malden, MA: Blackwell.

Crumley, Carole

1987 A dialectical critique of hierarchy, in Power Relations and State Formation: 155-169, ed. T. Patterson and C. Gailey. Washington, D.C.: American Anthropological Association.

Cugunov, Konstastin V., Hermann Parzinger, and Anatoli Nagler

2003 Der skythische Fürstengrabhügel von Arzan 2 in Tuva, Vorbericht der russischdeutschen Ausgrabungen 2000-2003. Eurasia Antiqua 9: 113-162. 
Davis-Kimball, Jeannine, Vladimir A. Bashilov, and Leonid T. Yablonsky, eds.

1995 Nomads of the Eurasian Steppes in the Early Iron Age. Berkeley: Zinat Press.

DeMarrais, Elizabeth, Luis Jaime Castillo, and Timothy Earle

1996 Ideology, materialization, and power strategies. Current Anthropology 37(1) : 15-31.

Di Cosmo, Nicola

2002 Ancient China and Its Enemies: The Rise of Nomadic Power in East Asian History. Cambridge: Cambridge University Press.

Dyson-Hudson, Rada, and Neville Dyson-Hudson

1980 Nomadic pastoralism. Annual Review of Anthropology 9:15-61.

EDMONDS, MARK

1999 Ancestral Geographies of the Neolithic. Oxford, UK: Routledge.

Ekvall, Robert B.

1968 Fields on the Hoof: Nexus of Tibetan Nomadic Pastoralism. New York: Holt, Rinehard, and Winston.

ERdenebaAtar, D.

2002 Mongol Nutgiin Dervolzhin Bylsh, Khirigsuuriin Soel. Ulaanbaatar: Mongolian Academy of Sciences.

Fernandez-Gimenez, M. E.

2000 The role of Mongolian nomadic pastoralists' ecological knowledge in rangeland management. Ecological Applications 10:1318-1326.

Fireman, Bruce, and Willam A. Gamson

1977 Utilitarian Logic in the Resource Mobilization Perspective. CRSO Working Paper \#153. Ann Arbor: Center for Research on Social Organization. Available for download at: http://deepblue.lib.umich.edu/bitstream/handle/2027.42/50928/153.pdf.

Fitzhugh, William W.

2009 The Mongolian deer stone-khirigsuur complex: Dating and organization of a Late Bronze Age menagerie, in Current Archaeological Research in Mongolia: 183-199, ed. J. Bemmann, H. Parzinger, E. Pohl, and D. Tseveendorzh. Bonn:Vor- und Frühgeschichtliche Archäologie Rheinische Friedrich-Wilhelms-Universität.

Fitzhugh, William W., and Jamsranjav Bayarsaikhan

2008 American-Mongolian Deer Stone Project: Field Report 2007. Washington, D.C., and Ulaanbaatar: The Arctic Studies Center, National Museum of Natural History, Smithsonian Institution and The National Museum of Mongolian History. Available for download at: http://www.mnh.si.edu/arctic/html/pub_field.html\#Mongoliareports.

FLEMING, ANDREW

1973 Tombs for the Living. Man 8(2):177-193.

Frachetti, Michael D.

2008 Pastoralist Landscapes and Social Interaction in Bronze Age Eurasia. Berkeley: University of California Press.

Frohlich, Bruno, Tsend Amgalantögs, Judith Littleton, David Hunt, Janine Hinton, and Kellyn Goler

2009 Bronze Age burial mounds in the Khövsgöl Aimag, Mongolia, in Current Archaeological Research In Mongolia: 99-115, ed. J. Bemmann, H. Parzinger, E. Pohl, and D. Tseveendorzh. Bonn: Vor- und Frühgeschichtliche Archäologie Rheinische Friedrich-Wilhelms-Universität.

Frohlich, Bruno, Tsend Amgalantugs, and David Hunt

2008 Bronze Age burial mound excavation in the Hovsgol Aimag, Northern Mongolia, in American-Mongolian Deer Stone Project: Field Report 2007: 101-103, ed. William W. Fitzhugh and Jamsranjav Bayarsaikhan. Washington D.C.: The Arctic Studies Center, National Museum of Natural History, Smithsonian Institution.

GLASSIE, Henry

1975 Folk Housing in Middle Virginia. Knoxville: The Unversity of Tennessee Press.

Görsdorf, Jochen, Hermann Parzinger, and Anatoli Nagler

2001 New radiocarbon dates of the North Asian Steppe Zone and its consequences for the chronology. Radiocarbon 43: 1115-1120. 
Gorynova, O. I.

1983 Bronze Age complex at the multilayer settlement of Tishikine III, in Research on the Ancient Cultures of Cisbaikal: 70-75, ed. P. B. Konavalov. Novosibirsk: Nauka.

Hall, Mark, William Honeychurch, Joshua Wright, Zagd Batsaikhan, and Luvganvandan Bilegt

1999 Chemical analysis of prehistoric Mongolian pottery. Arctic Anthropology 36(1-2) : 133-150.

Hall, Mark, and Sergei Minyaev

2002 Chemical analyses of Xiong-nu pottery: A preliminary study of exchange and trade on the Inner Asian steppe. Journal of Archaeological Science 29:135-144.

HANKS, BRYAN K.

2002 The Eurasian Steppe "nomadic world" of the first millennium BC: Inherent problems within the study of Iron Age nomadic groups, in Ancient Interactions: East and West in Eurasia: 183-197, ed. K. Boyle, C. Renfrew, and M. Levine. McDonald Institute Monographs. Cambridge: McDonald Institute for Archaeological Research.

Hegmon, Michelle

1989 The styles of integration: Ceramic style and Pueblo I integrative architecture in southwestern Colorado, in The Architecture of Social Integration in Prehistoric Pueblos, Occasional Papers of the Crow Canyon Archaeological Center, vol. 1:125-141, ed. W. D. Lipe and M. Hegmon. Cortez: Crow Canyon Archaeological Center.

Honeychurch, William, and Chunag Amartuvshin

2006 States on horseback: The rise of Inner Asian confederations and empires, in Archaeology of Asia: 255-278, ed. M. Stark. Malden, MA: Blackwell.

Honeychurch, William, Joshua Wright, and Chunag Amartuvshin

2009 Re-writing monumental landscapes as Inner Asian political process, in Monuments, Metals, and Mobility: Trajectories of Complexity in the Late Prehistory of the Eurasian Steppe: 330-357, ed. B. Hanks and K. Linduff. Cambridge: Cambridge University Press.

Houle, JeAn-Luc

2009 Socially integrative facilities and the emergence of social complexity on the Mongolian Steppe, in Social Complexity in Prehistoric Eurasia, Monuments, Metals and Mobility: 358-377, ed. B. K. Hanks and K. M. Linduff. Cambridge: Cambridge University Press.

Houle, Jean-Luc, and Dimmaazhav Erdenebaatar

2009 Investigating mobility, territoriality and complexity in the Late Bronze Age: An initial perspective from monuments and settlements, in Current Archaeological Research In Mongolia: 117-148, ed. J. Bemmann, H. Parzinger, E. Pohl, and D. Tseveendorzh. Bonn: Vor- und Frühgeschichtliche Archäologie Rheinische Friedrich-Wilhelms-Universität.

INGOLD, TIM

1993 The temporality of landscape. World Archaeology 25(2):153-174.

2000 The Perception of the Environment: Essays in Livelihood, Dwelling and Skill. New York: Routledge.

Jackson, Sarah E., AND Joshua Wright

forth- The work of monuments: Reflections on spatial, temporal, and social orientations in Mongolia coming and the Maya lowlands. Cambridge Archaeological Journal.

Jacobson-Tepfer, Esther, James E. Meacham, and Gary Tepfer

2010 Archaeology and Landscape in the Mongolian Altai: An Atlas. Redlands, CA: ESRI Press.

Jia, Peter, Wei Ming, Alison V. G. Betts, and Xinhua Wu

2009 Prehistoric archaeology in the Zhunge'er (Junggar) Basin, Xinjiang, China. Eurasian Prehistory 6(1-2): 167-198.

JOHNSON, MatTHEW

2002 Behind the Castle Gate: From Medieval to Renaissance. New York: Routledge.

Kantner, John, and Kevin J. Vaughn

2012 Pilgrimage as costly signal: Religiously motivated cooperation in Chaco and Nasca. Journal of Anthropological Archaeology $31: 66-82$.

Khazanov, Anatoli Mikhailovich

1979 Les formes de dépendance des agriculteurs par rapport aux nomades antiques des steppes eurasiatiques, in Terre et paysans dépendants dans les sociétés antiques: 229-247. Paris: Centre National de la Recherche Scientifique. 
Khudiakov, Iu. S.

1987 Khereksury i olennye kamni [Khirigsuurs and deer stones], in Arkheologiia, Etnografiia $i$ Anthropologiiia Mongolii: 136-162, ed. A. P. Derevianko and Sh. Natsagdorzh. Novosibirsk: Nauka.

Konovalov, P. B.

2008 The Burial Vault of a Xiongnu Prince at Sudzha (Il'movaia pad', Transbaikalia), trans. Daniel C. Waugh. Volume 3. Bonn: Vor- und Frühgeschichtliche Archäologie Rheinische FriedrichWilhelms-Universität.

Kovalev, Alexei A., and Dimmaazhav Erdenebaatar

2009 Discovery of new cultures of the Bronze Age in Mongolia according to the data obtained by the International Central Asian Archaeological Expedition, in Current Archaeological Research in Mongolia: 149-170, ed. J. Bemmann, H. Parzinger, E. Pohl, and D. Tseveendorzh. Bonn:Vorund Frühgeschichtliche Archäologie Rheinische Friedrich-Wilhelms-Universität.

Krader, LAWRENCE

1957 Culture and environment in interior Asia, in Studies in Human Ecology: 115-138, ed. L. Krader and A. Palerm. Washington D.C.: The Anthropological Society of Washington.

Kradin, Nikolay N.

2011 Heterarchy and hierarchy among the ancient Mongolian nomads. Social Evolution and History 10(1): 187-214.

Kubarev, V. D.

1991 Курганы Юстыда [Kurgans of Iustyda]. Новосибирск: Наука.

LAmberg-Karlovsky, C. C.

1994 The Bronze Age khanates of Central Asia. Antiquity 68:398-405.

Leone, Mark, and Paul Shackle

1990 Georgian order in Annapolis. Maryland Archaeology 26(1-2) : 69-84.

LeVy, JANET E.

1999 Gender, power and heterarchy in middle-level societies, in Manifesting Power: Gender and Interpretation of Power in Archaeology: 62-78, ed. T. L. Sweely. London: Routledge.

LEWIS, Mark EDWARD

1990 Sanctioned Violence in Early China. Albany: SUNY Press.

Lewis, R. Barry, Charles Stout, and Cameron B. Wesson

1998 The design of Mississippian towns, in Mississippian Towns and Sacred Spaces: Searching for an Architectural Grammar: 1-21, ed. R. B. Lewis and C. Stout. Tuscaloosa: The University of Alabama Press.

LightFoOt, Kent G.

1989 Complex societies in the prehistoric American Southwest: A consideration of the controversy, in The Sociopolitical Structure of Prehistoric Southwestern Societies: 3-30, ed. S. Upham, K. Lightfoot, and R. Jewett. Boulder: Westview.

Littleton, Judith, Bruce Floyd, Bruno Frohlich, Michael Dickson, Tsend Amgalantögs, Sarah

Karstens, and Kristen Pearlstein

2012 Taphonomic analysis of Bronze Age burials in Mongolian khirigsuurs. Journal of Archaeological Science 39:3361-3370.

Llobera, Marcos

2007 Reconstructing visual landscapes. World Archaeology 39(1):51-69.

Low, Setha M., and Denise Lawrence-Zúñiga

2003 Locating culture, in The Anthropology of Space and Place: 1-48, ed. S. M. Low and D. LawrenceZúñiga. Blackwell Readers in Anthropology. Malden, MA: Blackwell.

Magail, Jérôme, Pierre-Yves Milcent, Fabrice Laudrin, Jean François Bussiere, Chimiddorzh Erööl-Erdene, Zham'ian-Ombo Gantulga, Ronchinkhorloo Munkhtulga, and Makhbal Tsengel

2009 The Joint Monaco-Mongolian "Tsatsyn Ereg” Archaeological Expedition, in Current Archaeological Research in Mongolia: 171-181, ed. J. Bemmann, H. Parzinger, E. Pohl, and D. Tseveendorzh. Bonn: Vor- und Frühgeschichtliche Archäologie Rheinische FriedrichWilhelms-Universität. 
Makarewicz, Cheryl

2011 Xiongnu pastoral systems: Integrating economies of subsistence and scale, in Xiongnu Archaeology: Multidisciplinary Perspective on the First Steppe Empire in Central Asia: 181-192, ed. U. Brosseder and B. K. Miller. Bonn Contributions to Asian Archaeology. Bonn: Vor- und Frühgeschichtliche Archäologie Rheinische Friedrich-Wilhelms-Universität.

2014 Winter pasturing practices and variable fodder provisioning detected in nitrogen (d15N) and carbon (d13C) isotopes in sheep dentinal collagen. Journal of Archaeological Science 41: 502-510.

Marcolongo, Bruno, ed.

2005 General Report on the Fieldwork Conducted in 2005 by the Joint Italian-Mongolian CNR-MAS Expedition "Gobi Altayn Geo-Archaeology." Padova and Ulaanbaatar: La Garangola.

MeArns, RoBin

1993 Territoriality and land tenure among Mongolian pastoralists:Variation, continuity and change. Nomadic Peoples (33) : 73-103.

1996 Community, collective action and common grazing: The case of post-Socialist Mongolia. The Journal of Development Studies 32(3): 297-339.

Miller, Bryan K., Jamsranjav Bayarsaikhan, Tseveendorj Egimaa, and Christine Lee

2008 Xiongnu elite tomb complexes in the Mongolian Altai: Results of the Mongol-American Hovd Archaeology Project 2007. The Silk Road 5(2) :27-36.

Murphy, Daniel J.

In press Reviving the Xoroo: Risk, uncertainty, and the re-emergence of group mobility in rural Mongolia, in Mongolia after Socialism (in press), ed. Bruce Knauft et al. Ulaanbaatar: Admon Press. Draft paper available for download from http://uc.academia.edu/DanielMurphy.

Nomokonova, Tatiana, Robert J. Losey, Andrzej Weber, Ol'ga I. Goriunova, and Aleksei G. Novikov

2010 Late Holocene subsistence practices among Cis-Baikal pastoralists, Siberia: Zooarchaeological insights from Sagan-Zaba II. Asian Perspectives 49(1): 157-179.

OSTROM, ELINOR

2000 Collective action and the evolution of social norms. The Journal of Economic Perspectives 14(3): 137-158.

Parker Pearson, M., and Ramilisonina

1998 Stonehenge for the ancestors: The stones pass on the message. Antiquity 72:308-326.

Popova, Laura M. S.

2009 Blurring the boundaries: Foragers and pastoralists in the Volga-Urals region, in Social Complexity in Prehistoric Eurasia, Monuments, Metals and Mobility: 296-320, ed. B. K. Hanks and K. M. Linduff. Cambridge: Cambridge University Press.

Price, T. D.

1981 Complexity in "non-complex" societies, in Archaeological Approaches to the Study of Complexity: 51-97, ed. S. van der Leeuw. Amsterdam: University of Amsterdam.

Renfrew, Colin

1987 Archaeology and Language: The Puzzle of the Indo-European Origins. Cambridge: Cambridge University Press.

Richards, Colin

1993 Monumental choreography: Architecture and spatial representation in Late Neolithic Orkney, in Interpretative Archaeology: 143-178, ed. C. Tilley. London: Berg Publishers.

2005 Dwelling Among the Monuments, the Neolithic Village of Barnhouse, Maeshowe Passage Grave and Surrounding Monuments at Stenness, Orkney. Cambridge: McDonald Institute for Archaeological Research.

RoвB, John

2005 The extended artefact and the monumental economy: A methodology for material agency, in Rethinking Materiality: 131-139, ed. E. DeMarrais, C. Godsen, and C. Renfrew. Cambridge: McDonald Institute for Archaeological Research.

Roe, Emery, Lynn Huntsinger, and Keith Labnow

1998 High reliability pastoralism. Journal of Arid Environments 39:39-55.

Roscoe, Paul

2000 New Guinea leadership as ethnographic analogy: A critical review. Journal of Archaeological Method and Theory 7(2):79-118. 
SHELACH, GideON

2009 Prehistoric Societies on the Northern Frontiers of China. London: Equinox Publishing.

SherratT, ANDrew

2003 The horse and the wheel: The dialectics of change in the circum-Pontic region and adjacent areas, 4500-1500 BC, in Prehistoric Steppe Adaptation and the Horse. 233-252, ed. M. Levine, C. Renfrew, and K. Boyle. Cambridge: McDonald Institute.

Shishlina, N. I., A. L. Alexandrovsky, O. A. Chichagova, and J. van der Plicht

2000 Radiocarbon chronology of the Kalmykia Catacomb culture of the west Eurasian steppe. Antiquity 74:793-799.

Simukov, A. D.

(1934) Труды о Монголии и для Монголии [Works about Mongolia and for Mongolia]. Osaka: 2007 National Museum of Ethnology.

SINOR, DENIS

1969 Inner Asia, a Syllabus. Uralic and Altaic Series, vol. 96. Bloomington: Indiana University.

SINOR, DENIS, ED.

1990 The Cambridge History of Early Inner Asia. Cambridge: Cambridge University Press.

Smith, AdAm T.

2003 The Political Landscape, Constellations of Authority in Early Complex Polities. Berkeley: University of California Press.

Smith, Eric Alden, and Rebecca L. Bliege Bird

2000 Turtle hunting and tombstone opening: Public generosity as costly signaling. Evolution and Human Behavior $21: 245-261$.

Stark, Sören, Karen S. Rubinson, Zainolla S. Samashev, and Jennifer Y. Chi, eds.

2012 Nomads and Networks: The Ancient Art and Culture of Kazakhstan. New York: Institute for the Study of the Ancient World.

Takahama, Shu, and Toshio Hayashi

2003 Preliminary Report on Archaeological Investigations in Mongolia, 2003 by the Permanent Archaeological Joint Mongolian and Japanese Mission. Ulaanbaatar: Institute of Archaeology.

Takahama, Shu, Toshiki Yagyu, Yuko Tanaka, Tei Hatakeyama, and Toshio Hayashi

2004 Preliminary Report of the Archaeological Investigations in Mongolia, 2004 by the Permanent Archaeological Joint Mongolian and Japanese Mission. Ulaanbaatar: Institute of Archaeology.

TEKIN, TALAT

1969 A Grammar of Orkhon Turkic. Bloomington, IN: Research Center for the Language Sciences.

Tsybiktarov, A. D.

1995 Khereksury Buriatii, Severnoi i Tsentral'noi Mongolii [Khirigsuurs of Buriatiia and Northern and Central Mongolia], in Kul'tury i pamiatniki bronzovogo $i$ rannego zheleznogo vekov Zabaikal'ia $i$ Mongolii [Cultures and monuments of the Bronze and Early Iron Age of Zabaikal'e and Mongolia]: 38-47, ed. P. B. Konovalov. Ulan-Ude: Nauka.

Turbat, Ts., Сh. Amartuvshin, and U. Erdenbat

2003 Эгийн Гольн Сав Нутаг Дахь Археологийн Дурсгалууд [Archaeological Monuments of Egiin GolValley]. Ulaanbataar: Mongolian Academy of Science, Institute of Archaeology.

Vainshtein, Sevyan

1980 Nomads of South Siberia, The Pastoral Economies of Tuva. Cambridge: Cambridge University Press.

WATSON, BURTON

1961 Records of the Grand Historian of China, translated from the Shih Chi of Ssu-ma Ch'ien, vol. 2. New York: Columbia University Press.

Weber, ANDRZEJ

1995 Neolithic and early Bronze Age of the Lake Baikal region: A review of recent research. Journal of World Prehistory 9(1):99-165.

WENKe, RoberT

1991 The evolution of early Egyptian civilizations. Journal of World Prehistory 5(3) : 279-329.

WRIGHT, JOSHUA

2006 The Adoption of Pastoralism in Northeast Asia: Monumental Transformation in the Egiin Gol Valley, Mongolia. Ph.D. diss., Harvard University. 
2007 Organization principles of khirigsuur monuments in the Lower Egiin Gol valley, Mongolia. Journal of Anthropological Archaeology 26:350-365.

2012 Temporal perspectives on the monumental constellations of Inner Asia, in "As Time Goes By?": Monumentality, Landscapes and the Temporal Perspective: 73-83, ed. M. Furholt, M. Hinz, and D. Mischka. Bonn: Verlag Dr. Rudolf Habelt GmbH.

2014 Inequality on the surface: Horses, power, and practice in the Eurasian Bronze Age, in Animals and Inequality in the Ancient World, ed. S. McCarty and B. Arbuckle. Boulder: University Press of Colorado.

Wright, Joshua, William Honeychurch, and Chunag Amartuvshin

2007 Initial findings of the Baga Gazaryn Chuluu archaeological survey (2003-2006). Antiquity 81(313). Available at: http://antiquity.ac.uk/ProjGall/wright/index.html.

forth- Continuity and Authority in the Mongolian Steppe, The Egiin Gol Survey 1997-2002. New Haven: coming Yale Anthropological Press.

Xie, YinA, AND Wenjun Li

2008 Why do herders insist on Otor? Maintaining mobility in Inner Mongolia. Nomadic Peoples $12(2): 35-52$.

ZADNEPROVSKIY, Y. A.

1994 The nomads of northern Central Asia after the invasion of Alexander, in History of Civilizations of Central Asia: The Development of Sedentary and Nomadic Civilization 700 B.C. to A.D. 250:457-472, ed. J. Harmatta, B. N. Puri, and G. F. Etemadi. Paris: UNESCO.

\begin{abstract}
Khirigsuurs are stone monuments of variable scale and complexity that dominate the archaeological landscape of the Mongolian Bronze Age. Though there are countless typical-sized monuments, there are a few very large structures suggesting that a chiefly hierarchy directed their construction. Using measurements of size and formal complexity to compare these mega-monuments and khirigsuurs within fully surveyed areas this article argues that these monuments are not primarily tombs built to represent the social hierarchy of early nomadic pastoralists. Instead, they are monumental places created for living communities to communicate their organization and enduring nature to others and themselves. This communication was essential for early pastoralist communities to become established and survive. Keywords: Mongolia, Bronze Age, monuments, pastoralism, heterarchy, collective action.
\end{abstract}

